\title{
1 Personal Nitrogen Footprint Tool for the United Kingdom
}

2 Carly J. Stevens, ${ }^{* a}$ Allison M. Leach, ${ }^{\mathrm{b}}$ Sarah Dale, ${ }^{\mathrm{a}}$ James N. Galloway ${ }^{\mathrm{b}}$

3

$4 \quad{ }^{a}$ Lancaster Environment Centre, Lancaster University, Lancaster, LA1 4YQ, IK

$5 \quad{ }^{\mathrm{b}}$ Environmental Sciences Department, University of Virginia, Charlottesville, Virginia, USA

6

7 *to whom correspondence should be addressed. C.Stevens@lancaster.ac.uk

8

\section{Abstract}

10 The global nitrogen $(\mathrm{N})$ cycle has been transformed by human use of reactive $\mathrm{N}$ as a

11 consequence of increased demand for food and energy. Given the considerable impact of humans on the $\mathrm{N}$ cycle, it is essential that we raise awareness amongst the public and policy makers as this is the first step in providing individuals and governments the opportunity to reduce their impact on the $\mathrm{N}$ cycle and reduce the environmental and health consequences of $\mathrm{N}$ pollution. Here we describe an $\mathrm{N}$ footprint tool for the UK developed as part of the NPRINT program. The current per capita $\mathrm{N}$ footprint in the UK is $27.1 \mathrm{~kg} \mathrm{~N} /$ capita/yr with food production constituting the largest proportion of the footprint (18.0 kg N/capita/yr). Calculating an $\mathrm{N}$ footprint for $1971(26.0 \mathrm{~kg} \mathrm{~N} /$ capita/yr) demonstrates that per capita $\mathrm{N}$ footprints have increased slightly. The average UK footprint is smaller than that found in the USA but is higher than The Netherlands and Germany. Scenario analysis demonstrates that reducing food protein consumption to the levels recommended by the FAO and World Health Organization reduces the overall $\mathrm{N}$ footprint by $33 \%$. Consuming a vegetarian diet and consuming only sustainable food both decreased the $\mathrm{N}$ footprint by $15 \%$ but changes in energy use have a much smaller impact. 
The global nitrogen $(\mathrm{N})$ cycle is being transformed at a record pace. Between 1860 and 2010 anthropogenic creation of reactive $\mathrm{N}(\mathrm{Nr})$ increased more than ten-fold from 15 to $210 \mathrm{Tg}$ $\mathrm{N} /$ year $^{1}$. The reasons behind the increases in $\mathrm{Nr}$ production are clearly understood; between 1860 and 2010 energy and food production not only increased with the rapidly growing world population, but per capita use also increased. Globally crop and meat production has had to increase to meet the demands of the growing human population. A substantial proportion of grain production is used for animal feed, over half of the grain produced in the US is used as feed crops ${ }^{2}$. In addition, between 1961 and 2007, per capita demand for crop calories and protein also increased steadily, with demand closely related to gross domestic product (GDP)

3. This has been made possible with the Haber-Bosch process, which has created an essentially endless supply of synthetic fertilizer for food production and is now the major source of $\mathrm{Nr}$ to the global terrestrial environment. Energy production by fossil fuel combustion has also increased rapidly with large increases in the developing world (Galloway et al., 2008; Fowler et al., 2013).

Severe inefficiencies in $\mathrm{Nr}$ use in agricultural systems have led to a scientific challenge to control the fate of $\mathrm{Nr}$ in cropping systems. These systems are under intense pressure to sustain high yields due to the world's limited supply of productive land ${ }^{4}$. Furthermore, without emissions controls, all of the $\mathrm{Nr}$ produced during energy production by fossil fuel combustion is lost to the environment. A wide range of environmental problems can be observed as a consequence of increasing $\mathrm{Nr}$ in the environment. For example, in the atmosphere $\mathrm{Nr}$ adds to particulate matter, smog, stratospheric ozone depletion, and an enhanced greenhouse effect; in terrestrial ecosystems it contributes to biodiversity loss, forest dieback, and soil acidification; and in marine and freshwater ecosystems it contributes to 
ocean acidification and eutrophication, which are related to biodiversity loss and algal blooms ${ }^{5}$. These impacts are all linked via the $\mathrm{N}$ cascade, the transfer of $\mathrm{Nr}$ between ecosystems by multiple pathways ${ }^{6}$. Excess $\mathrm{Nr}$ also impacts human health. Although $\mathrm{Nr}$ availability brings benefits through increased crop production, high levels of food production have led to unbalanced diets with high levels of meat consumption ${ }^{2}$. High levels of $\mathrm{Nr}$ in water and air have been linked to human ailments, diseases and allergies ${ }^{7}$.

In the United Kingdom (UK), changes in the use of $\mathrm{Nr}$ through food and energy consumption reflect global patterns. Between 1961 and 2009 supply of the majority of food types increased in the UK. In the case of alcoholic beverages, cereals, starchy roots, and meat, increases in supply between 1961 and 2009 are in excess of one million tonnes. The supply of vegetables increased by more than two million tonnes in this period, milk by over three million tonnes, and fruit by more than four million tonnes (Figure 1). Over a similar time period (1970 to 2012) total combustion of fossil fuels and demand for energy has fallen very slightly in the UK, although current levels are not the lowest during this period. Declines have mostly been seen in the energy use within industry, possibly due to a combination of increased energy use efficiency and declining industry in the UK. There have been substantial increases in energy use within transport (Figure 2) ${ }^{8}$.

The abundance of $\mathrm{Nr}$ in the environment has been increased by human activity more than any other chemical element ${ }^{9}$. Globally humans contribute approximately double the amount of $\mathrm{N}$ to the environment that natural processes do ${ }^{10}$ whereas for $\mathrm{CO}_{2}$ emissions, human activities contribute between 5 and $10 \%{ }^{11}$. With this considerable impact of humans on the N cycle, it is essential that we raise awareness amongst the public and policy makers. Raising awareness is the first step in giving individuals and governments the opportunity to reduce their impact on the $\mathrm{N}$ cycle and reduce the environmental and health consequences of $\mathrm{N}$ pollution. As a step towards this an international team of scientists have been developing a 
group of tools in the N-PRINT program (www.n-print.org). These tools will ultimately be able to describe losses of $\mathrm{Nr}$ associated with consumption patterns of an entity, such as an individual or an institution. Links will then be made to its impact on the environment from individual consumers and collective consumption behaviour together with identifying ways that policy can influence these losses ${ }^{10}$.

In this paper we focus on the $\mathrm{N}$-Calculator tool, which is an $\mathrm{N}$ footprint tool individuals can use to calculate the $\mathrm{Nr}$ lost to the environment from the food they eat, the energy they use, and the goods and services they use. An $\mathrm{N}$ footprint is defined as the total amount of reactive $\mathrm{N}$ released to the environment as a result of an entity's resource consumption. The tool provides an assessment of not only the $\mathrm{Nr}$ in food and energy consumed by the individuals, but also the release of $\mathrm{Nr}$ through the production of food, energy, goods and services used by individuals. This tool helps consumers connect their consumption patterns to the $\mathrm{N}$ cycle.

Nitrogen calculators have already been developed for the USA, Netherlands, and Germany; the model is described in detail in Leach et al. ${ }^{10}$. In this paper we present an $\mathrm{N}$ footprint tool for the United Kingdom (UK). We also make comparisons with other countries for which we have $\mathrm{N}$ footprints available, examine how the $\mathrm{N}$ footprint has changed over time in the $\mathrm{UK}$, and present scenarios for $\mathrm{N}$ footprints in the UK based on changes in resource use.

\section{Methods}

The methods for the UK N-Calculator follow those described in Leach et al. ${ }^{10}$. The $\mathrm{N}$ footprint is composed of two distinct parts: food and energy.

97 A food $\mathrm{N}$ footprint is the sum of the food consumption and food production $\mathrm{N}$ footprint. For the UK, the food consumption component was first determined using FAO food supply data 
and protein content for the UK using the base year $2007^{8}$. Food protein supply is multiplied by the $\mathrm{N}$ content and and average food waste data for Europe ${ }^{12}$ is subtracted. The average rate of denitrification at sewage treatment plants (Anglian Water, personal communication) was applied to the food consumption $\mathrm{N}$ footprint. Food production was then addressed by modifying the US virtual $\mathrm{N}$ factors (VNF), which describe the average amount of reactive $\mathrm{N}$ released to the environment per unit of $\mathrm{N}$ consumption ${ }^{10}$. The VNF includes all $\mathrm{Nr}$ losses from the system such as fertiliser not incorporated into the plant and crop residues not used as food. For every stage of the food production process six $\mathrm{N}$ parameters were considered: Available $\mathrm{N}, \%$ of previous $\mathrm{N}$ available, $\mathrm{N}$ waste produced, $\% \mathrm{~N}$ recycled, $\mathrm{N}$ recycled, and $\mathrm{N}$ loss. Developed for specific food types, the US VNF data were modified only for the final two stages of food production (processing and food waste) with Europe-specific food waste figures (Table 1). The modified US VNF were considered appropriate to use for the UK because food production in the two developed countries is dominated by conventional, industrial processes ${ }^{13}$. Using individual consumption based on answering questions on amount of food portions consumed, values can be translated into a personal food footprint.

The UK energy $\mathrm{N}$ footprint was determined using a combination of a bottom-up and topdown approach. The bottom up approach is calculated by collecting housing and transport energy consumption data and multiplying it by $\mathrm{NO}_{\mathrm{x}}$ emission factors ${ }^{14-15}$ for the major types of energy consumption in the UK to give total emissions. Housing energy use included electricity ${ }^{16}$, natural gas ${ }^{17}$, wood, solar and geothermal ${ }^{18}$. Housing energy use per household was divided by mean number of persons per household ${ }^{19}$. The addition of alternative fuels, such as wood and renewables, is unique from the US N-Calculator. Transport energy use included personal petrol car, diesel car, and motorcycle, public bus and rail ${ }^{20}$, and airplane ${ }^{21}$. Public transport and airplane use was corrected for average number of passengers per vehicle 21-22. The final component of the UK energy $\mathrm{N}$ footprint was calculated using an 
environmentally extended input output (EEIO) analysis, a procedure that is widely used for

125 footprint and sustainable consumption analyses ${ }^{23-25}$. This analysis utilises economic inputoutput tables and sector level emissions to allocate national $\mathrm{N}$ emissions to personal consumption patterns in all categories of the footprint: food, housing, transport, goods, and services. Nitrogen emissions calculated from the bottom-up approach described above were subtracted from the findings of the EEIO analysis to avoid double-counting. Using values on individual energy consumption and distances travelled values can be calculated for individual $\mathrm{N}$ footprints.

An $\mathrm{N}$ footprint was compiled for the year 1970 to provide temporal comparison. The year 1970 was selected because it was the oldest year for which all necessary data were available. Food consumption and protein content data were taken from FAOSTAT ${ }^{8}$. Food waste and virtual $\mathrm{N}$ footprints were unchanged from the 2007 model. The rate of denitrification at sewage treatment plants was assumed to be zero in 1970. Energy consumption data for the UK were taken from $\mathrm{DECC}^{26}$ incorporating values for the number of UK households ${ }^{27}$. 138 Transport data were taken from national datasets ${ }^{22,28}$. Emission factors for 1970 were taken from the NAEI database ${ }^{14}$ and used to calculate percentage change in emission factors. The UK N-calculator was compared to existing calculators in the US, Netherlands, Germany and the US ${ }^{10}$.

The current UK N-Calculator (2007) was used to test scenarios to see how the average UK N footprint would be affected by changes in consumption patterns. The following scenarios were considered:

1. Recommended protein: Protein consumption is reduced to the level recommended by the FAO and World Health Organization (3 kg N/capita/yr), with the dietary composition otherwise remaining the same ${ }^{29-30}$. 
2. Vegetarian diet: Meat protein consumption is replaced by vegetable, dairy, and egg protein. Total protein consumption remains the same as current consumption levels.

3. 50\% food waste: Food waste is reduced by half. The current diet is used.

4. Sustainable food: Only food produced sustainably in terms of $\mathrm{N}$ is consumed. Sustainable food is defined here as the efficiency possible with currently available technology, as defined by the USEPA Science Advisory Board ${ }^{31}$. The possible $\mathrm{N}$ efficiency improvements and emissions avoidance for the US were applied to the UK VNF, assuming that the same efficiency improvements could be achieved in the UK.

5. Advanced WWTP (wastewater treatment plant): Advanced sewage treatment with denitrification to remove $\mathrm{Nr}$ is expanded from current levels (2\%) to $100 \%$ of the country's population. Treatment is assumed to denitrify $70 \%$ of the reactive $\mathrm{N}$ in human waste ${ }^{32}$.

6. Renewable energy: Switch from coal and gas consumption to only renewable energy.

7. Public transit: Replace $50 \%$ of personal car travel with travel by bus and rail.

8. Combination: Accomplish all analysed scenarios (\#1-7).

\section{Results}

The current per capita $\mathrm{N}$ footprint in the UK is $27.1 \mathrm{~kg} \mathrm{~N} /$ capita/yr (Table 2). The footprint is dominated by the food production sector $(18.0 \mathrm{~kg} \mathrm{~N} / \mathrm{capita} / \mathrm{yr})$. The average rate of $\mathrm{N}$ consumption is $5.0 \mathrm{~kg} \mathrm{~N} /$ capita/yr, but the $2 \%$ rate of denitrification during sewage treatment (Anglian Water, personal communication) reduces the food consumption $\mathrm{N}$ footprint to 4.9 $\mathrm{kg} \mathrm{N} / \mathrm{capita} / \mathrm{yr}$. The energy sectors contribute the remaining $4.2 \mathrm{~kg} \mathrm{~N} / \mathrm{capita} / \mathrm{yr}$. 
small difference which masks quite large changes in some components of the British diet

174

175

176

177

(Table 3). In 1970 there was generally more red meat, offal, and eggs consumed per capita whereas in 2007 there was more poultry meat, milk, cheese, cereals and fruit and vegetables consumed. Differences in household energy use represent the category with the largest difference between 1970 and 2007, increasing from 1.3 to $2.0 \mathrm{Kg} \mathrm{N}$ per capita (Table 2). There are large increases in electricity and gas use, although this is partially offset by a reduction in the emission factor for electricity (Table 3). Unfortunately information was not available for the emission factor for natural gas in 1970. For transport there is the same footprint in 1970 as 2007 (Table 2) but distance travelled by private car is higher in 2007 than 1970. Emission factors are considerably reduced for petrol and lower for diesel. Bus travel has reduced but train travel has increased, although both show reduced emission factors. Air travel is reduced but unfortunately there was insufficient information available to calculate comparable emission factors so the 2007 emission factor was used for the 1970 footprint.

Comparison between national $\mathrm{N}$ footprints for the United States, Netherlands, Germany and UK reveals differences in $\mathrm{N}$ released from food consumption, food production, housing and transport (Figure 3). Overall the US has the largest $\mathrm{N}$ footprint followed by the UK, Germany and The Netherlands. $\mathrm{N}$ losses due to food consumption are similar in the US and UK but lower in The Netherlands and Germany. Energy consumption in housing is highest in the US followed by Germany, with The Netherlands and UK having similar lower values. $\mathrm{N}$ losses due to transport are considerably higher in the US than European countries investigated, with the UK and The Netherlands showing the lowest values.

\section{Food and energy scenarios were tested to reveal how an individual's $\mathrm{N}$ footprint could} change as a result of changes in consumption patterns. Of the individual scenarios tested, 
reducing food protein consumption to the recommended level had the biggest impact, reducing the overall $\mathrm{N}$ footprint by $33 \%$ (Figure 4). Consuming a vegetarian diet and consuming only sustainable food both decreased the $\mathrm{N}$ footprint by $15 \%$. The energy scenarios had a smaller impact. Replacing all household fossil fuel use with renewable energy use reduced the footprint by just $4 \%$, and replacing car travel with public transit did not have a measurable impact. A combined scenario that took into account reductions from all scenarios led to a total $\mathrm{N}$ footprint reduction of $63 \%$, from $27.1 \mathrm{~kg} \mathrm{~N} / \mathrm{cap} / \mathrm{yr}$ to $10.0 \mathrm{~kg}$ N/cap/yr.

\section{Discussion}

Footprint tools provide a readily understandable metric of human impact on the natural world and have been used extensively in recent years for carbon emissions, water use, and impact on the environment with ecological footprints. The $\mathrm{N}$ footprint tool is a unique tool allowing people to calculate their own person impact on the $\mathrm{N}$ cycle. Awareness of the disruption of the global $\mathrm{N}$ cycle amongst the public and policy makers is generally poor so this tool provides an essential communication device to demonstrate how changes in diet and lifestyle can reduce individual impacts on the production of $\mathrm{Nr}$. The tool is available on the N-PRINT website (www.n-print.org).

The relatively small increase of $1.1 \mathrm{~kg} \mathrm{~N}$ in the average $\mathrm{N}$ footprint between 1970 and 2007 in the UK masks some considerable changes in consumption patterns and emissions between different sources. These changes reflect a broad range of lifestyle changes that have been seen in the UK over the last forty years. Since 1970 the proportion of people in higher education has increased from 621,000 to 2.5 million, less people are getting married, households are smaller, women are having their first child later and life expectancy has 
increased $^{33}$.

Food is the most significant component of the $\mathrm{N}$ footprint. Food contributes to the $\mathrm{N}$ footprint increase in the average $\mathrm{N}$ footprint from diet, but this result obscures considerable changes in the supply of different food categories. For example, per capita consumption of pigmeat, bovine meat, animal fats and offals have all fallen. A survey of UK residents published in 2003 indicated that over a quarter of UK residents considered themselves to be reducing meat consumption due to concern over healthiness, taste, value for money, and ethical concerns ${ }^{34}$. A number of studies have reported an association of red meat with cardiovascular disease and cancer. In addition, concerns over the safety of beef related to the bovine spongiform encephalopathy (BSE) outbreak may have reduced the consumption of red meat ${ }^{35-36}$. Egg consumption has also declined, possibly related to the salmonella scare in 1989, growing awareness of diet and awareness of issues concerning bird welfare ${ }^{37}$. This has been replaced by higher consumption of white meat, milk, cheese, cereals, fruit and vegetables and an increase in the total food supply for animal and vegetable products per person per year. In this example we kept the N efficiency in food production constant between 1970 and 2007, although it is likely this provides an underestimate since fertiliser use in tillage crops in England and Wales increased from 84 to $152 \mathrm{~kg} \mathrm{ha}^{-1}$ between 1970 and 2007 whilst to grass crops it increased and declined again, resulting in little change ${ }^{38}$.

Energy consumption and transport both release $\mathrm{N}$ through the combustion of fossil fuels, which releases $\mathrm{NO}_{\mathrm{x}}$ emissions. Household energy use makes a comparatively small contribution to the overall $\mathrm{N}$ footprint compared to that from food. Electricity and natural gas use increased considerably between 1970 and 2007, which is likely to be at least related to 
248 the dramatic rise in the use of consumer electronics in households ${ }^{39}$. Transport shows no

249 change in its footprint, but this conceals large increases in vehicle use. In $197048 \%$ of

250

251

252

253

254

255

256

257

258

259

260

261

262

263

264

265

266

267

268

269

270

271 households in Great Britain did not have regular use of a car, and in 2008 this was reduced to $22 \%$ of households. However, this change in car use is offset by massive reductions in emission factors brought about by both improvements in engine design and fitting three-way catalysts to petrol cars ${ }^{40}$.

There is a substantial difference in the $\mathrm{N}$ footprints between countries. Food production values were not fully adapted for individual countries due to a shortage of information but in other sectors there are noticeable differences between the US and Europe. The N footprint associated with food consumption is considerably higher in the US than either the Netherlands or Germany. Leach et al. ${ }^{10}$ compared the $\mathrm{N}$ footprints of the US and Netherlands, reporting that a higher proportion of the footprint came from meat $\mathrm{N}$ in the US compared to the Netherlands where the main contributors were dairy, milk and fish. The food consumption footprint in Germany is only marginally higher. In contrast the UK has an N footprint from food consumption almost as high as the US, which is partly accounted for by high meat and dairy consumption. Another factor in this part of the $\mathrm{N}$ footprint is the use of advanced sewage treatment with nutrient removal technology. Almost the entire Netherlands is serviced by advanced wastewater treatment meaning that $78 \%$ of the food consumption $\mathrm{N}$ footprint is removed by advanced wastewater treatment ${ }^{41}$. In the US and the UK advanced sewage treatment with nutrient removal is much less extensive covering $5 \%$ of the US ${ }^{10}$ and $2 \%$ of the UK (Anglian Water, personal communication).

Energy use is also lower in Europe than the US. The largest difference can be seen in the transport sector. On average Americans drive $400 \mathrm{~km}$ per week but in the UK this is $164 \mathrm{~km}$ 
per week. The US is the country with the highest dependence on automobiles in urban areas in the world with levels much higher than other countries. This is related to wealth, land use patterns, transport infrastructure priorities and transit provision ${ }^{42}$. Public transport is much more widely used in Europe than the US; emissions from public transport are smaller than from personal vehicles resulting in a much smaller impact on the $\mathrm{N}$ footprint. The US also has higher household energy consumption than European countries. Differences between countries in Europe are relatively small, although energy use in housing is higher in the UK than the Netherlands and Germany.

The footprint scenario analysis in the UK shows the potential for changes in personal consumption patterns on the use and loss of $\mathrm{Nr}$. The food scenarios all had a larger impact than the energy scenarios. Combining all analysed scenarios led to an overall $\mathrm{N}$ footprint reduction of $63 \%$. Scaled up to the population of the UK, this could lead to an annual reduction in $\mathrm{Nr}$ losses of approximately $1 \mathrm{Tg} \mathrm{Nr}$. However some of the scenarios are easier than others to achieve on a personal level. For example, individuals can generally choose how much food they eat, what types of food they eat, and how they manage their food waste. Consumers do not have control over the treatment level at their local wastewater treatment plant. Some scenarios, such as the consumption of sustainable food and the exclusive use of renewable energy sources, could also be cost-prohibitive. However most of the analysed scenarios are achievable on a personal level and can have a substantial impact on $\mathrm{Nr}$ losses, especially when adopted at a large scale.

\section{Conclusion}

Anthropogenic $\mathrm{N}$ use and loss rates are increasing on a global scale and are expected to continue to increase with population growth and shifting dietary patterns. The UK $\mathrm{N}$ footprint 
has only increased slightly since 1970 , but the total $\mathrm{Nr}$ loss is magnified by population growth. The negative environmental and human health consequences of excess $\mathrm{Nr}$ require action to reduce $\mathrm{Nr}$ loss to the environment. One way to achieve these reductions is through changes in personal consumption patterns. The UK N-Calculator informs consumers about how $\mathrm{N}$ is released to the environment and how their personal choices impact those $\mathrm{Nr}$ losses. Individuals can choose from a variety of changes in personal consumption patterns to reduce their impact, with significant reductions possible. These personal consumption changes, combined with increased efficiency at the production level, will reduce the loss of $\mathrm{Nr}$ and its detrimental consequences.

\section{Acknowledgments}

This project was funded by the NERC Macronutrient Cycles Programme.

\section{References}

1. D. Fowler, M. Coyle, U. Skiba, M. A. Sutton, J. N. Cape, S. Reis, L. J. Sheppard, A. Jenkins, B. Grizzetti, J. N. Galloway, P. Vitousek, A. M. Leach, A. F. Bouwman, K. Butterbach-Bahl, F. Dentener, D. Stevenson, M. Amann and M. Voss, Philosophical Transactions of The Royal Society B, 2013, 368, 20130164.

2. R. W. Howarth, E. W. Boyer, W. J. Pabich and J. N. Galloway, Ambio, 2002, 31, 8896.

3. D. Tilman, C. Blazer, J. Hill and B. L. Befort, Proceedings of the National Academy of Sciences, 2011, 108, 20260-20264.

4. K. G. Cassman, A. Dobermann and D. T. Walters, Ambio, 2002, 31. 
5. M. A. Sutton, C. M. Howard, J. W. Erisman, G. Billen, A. Bleeker, P. Grennfelt, H. Van Grinsven and B. Grizzetti, eds., The European Nitrogen Assessment: Sources, effects and policy perspectives, Cambridge University Press, Cambridge, 2011.

6. J. N. Galloway, J. D. Aber, J. W. Erisman, S. P. Seitzinger, R. W. Howarth, E. B. Cowling and B. J. Cosby, BioScience, 2003, 53, 341-356.

7. A. R. Townsend, R. W. Howarth, F. Bazzaz, M. S. Booth, C. C. Cleveland, S. K. Collinge, A. P. Dobson, P. R. Epstein, E. A. Holland, D. R. Keeney, M. A. Mallin, C. A. Rogers, P. Wayne and A. H. Wolfe, Frontiers in Ecology and Environment, 2003, $1,240-246$.

8. Food and Agriculture Organization of the United Nations, FAO STAT, http://faostat.fao.org/site/345/default.aspx, Accessed September 2013.

9. J. W. Erisman, A. Bleeker, A. Hensen and A. Vermeulen, Atmos. Environ., 2008, 42, 3209-3217.

10. A. M. Leach, J. N. Galloway, A. Bleeker, J. W. Erisman, R. Kohn and J. Kitzes, Environmental Development, 2012, 1, 40-66.

11. C. Le Quéré, Environmental Sustainability, 2010, 2, 219-224.

12. J. Gustavsson, C. Cederberg, U. Sonesson, R. van Otterdijk and A. Meybeck, Global food losses and food waste, FAO, Rome, 2011.

13. The World Bank, Indicators, http://data.worldbank.org/indicator, Accessed November 2013.

14. National Atmospheric Emissions Inventory, http://naei.defra.gov.uk/data/ef-all.

15. EMEP, EMEP/EEA air pollutant emission inventory guidebook 2013 European Environment Agency, Copenhagen, 2013. 
16. Department of Energy and Climate Change, Sub-national gas consumption data http://www.decc.gov.uk/en/content/cms/statistics/energy_stats/regional/gas/gas.aspx, Accessed August 2013.

17. Department of Energy and Climate Change, Sub-national energy consumption,

24. R. E. Miller and P. D.

D. Blair, Input-Output Analysis: Foundations and extensions, 
25. T. Wiedmann, J. Minx, J. Barrett and M. Wackernage, Ecological Economics, 2006, $56,28-48$.

26. Department for Transport, National travel survey statistics, http://www.dft.gov.uk/statistics/series/national-travel-survey/, Accessed August 2013.

27. M. T. Programme, BNXS25: UK Household and Population Figures 1970 - 2020, Defra, London, 2007.

28. Office for National Statistics, Social Trends No. 38, National Statistics, Cardiff, 2006.

29. Institute of Medicine, Dietary reference intakes for energy, carbohydrate, fiber, fat, fatty acids, cholesterol, protein, and amino acids (macronutrients). Institute of Medicine of The National Academies, Washington D.C., 2005.

30. World Health Organization, Food and Agriculture Organization of the United Nations and United Nations University, Protein and amino acid requirements in human nutrition: Report of a joint FAO/WHO/UNU expert consultation World Health Organization, Geneva, 2007.

31. EPA Science Advisory Board, Reactive nitrogen in the United States: An analysis of inputs, flows, consequences and management options., Report EPA-SAB-11-013, U.S. Environmental Protection Agency, Washington D.C., 2011.

32. L. Metcalf, H. P. Eddy and G. Tchobanoglous, Wastewater engineering - Treatment and reuse McGraw-Hill, New York, Fourth edn., 2002.

33. Office for National Statistics, Social Trends No. 40, National Statistics, Cardiff, 2010.

34. N. J. Richardson, N. A. Shepherd and N. A. Elliman, Appetite, 1993, 21, 41-51.

35. A. J. McAfee, E. M. McSorley, G. J. Cuskelly, B. W. Moss, J. M. W. Wallace, M. P. Bonham and A. M. Fearon, Meat Science, 2010, 84, 1-13.

36. W. Verbeke, L. J. Frewer, J. Scholderer and H. F. De Brabander, Analytica Chimica Acta, 2007, 586, 2-7. 
393 37. A. Fearne and D. Lavelle, British Food Journal, 1996, 98, 7-12.

394 38. Defra, The British survey of fertiliser practice, Defra, London, 2008.

395 39. T. Crosbie, Energy Policy, 2008, 36, 2191-2199.

396 40. Air Quality Expert Group, Nitrogen dioxide in the United Kingdom, Defra, London, 3972004.

398 41. U. van Waterschappen, Clean waste water: National comparison of the regional water authorities with respect to their water quality management (in Dutch), 2006.

400 42. J. R. Kenworthy and F. B. Laube, Environmental Impact Assessment Reviews, 1996, 401 $16,279-308$.

402 43. Department of Energy and Climate Change, Energy consumption in the UK (2013), Department of Energy and Climate Change, London, 2013. 
407 Table 1. Comparison of virtual $\mathrm{N}$ factors for the United States and the United Kingdom, by food type.

\begin{tabular}{|l|l|l|}
\hline Food type & $\begin{array}{l}\text { United States } \\
\text { virtual N factor }\end{array}$ & $\begin{array}{l}\text { United Kingdom } \\
\text { virtual N factor }\end{array}$ \\
\hline Poultry & 3.2 & 3.2 \\
\hline Pigmeat & 4.4 & 4.4 \\
\hline Beef & 7.9 & 7.9 \\
\hline Milk & 4.3 & 3.9 \\
\hline Fish & 4.1 & 2.9 \\
\hline Cereals & 1.4 & 1.3 \\
\hline Pulses & 0.5 & 0.5 \\
\hline Starchy roots & 1.5 & 1.1 \\
\hline Vegetables & 9.6 & 8.2 \\
\hline
\end{tabular}

408

409

410

Table 2. Nitrogen footprint for the UK in 1970 and 2007.

\begin{tabular}{|l|l|l|}
\hline & $\mathbf{1 9 7 0}$ & $\mathbf{2 0 0 7}$ \\
& & N footprint $(\mathbf{k g} \mathbf{~})$ \\
\hline Food consumption & 4.6 & 4.9 \\
\hline Food production & 17.9 & 18.0 \\
\hline Housing & 1.3 & 2.0 \\
\hline Transport & 1.1 & 1.1 \\
\hline Goods and Services & 1.1 & 1.1 \\
\hline Total & $\mathbf{2 6 . 0}$ & $\mathbf{2 7 . 1}$ \\
\hline
\end{tabular}


417 Table 3. Information used in calculating the national average UK footprint for food consumption, energy use and transport in the UK in 1970 and 2007.

\begin{tabular}{|c|c|c|c|c|}
\hline \multirow{2}{*}{\begin{tabular}{|l|} 
Product \\
Food
\end{tabular}} & \multicolumn{2}{|l|}{1970} & \multicolumn{2}{|l|}{2007} \\
\hline & $\begin{array}{l}\text { Food supply } \\
\left(\text { kg capita }^{-1} \text { year }^{-1}\right)\end{array}$ & $\begin{array}{l}\text { Protein supply } \\
\left(\text { g capita }^{-1} \text { day }^{-1}\right)\end{array}$ & $\begin{array}{l}\text { Food supply } \\
\left(\text { kg capita }^{-1} \text { year }^{-1}\right)\end{array}$ & $\begin{array}{l}\text { Protein supply } \\
\left(\text { g capita }^{-1} \text { day }^{-1}\right)\end{array}$ \\
\hline \multicolumn{5}{|c|}{ Animal products } \\
\hline Poultry meat & 10.5 & 4.2 & 32.2 & 13.0 \\
\hline Pigmeat & 27.5 & 7.6 & 26.2 & 7.2 \\
\hline Bovine meat & 24.1 & 8.5 & 19.8 & 7.1 \\
\hline Milk & 231.6 & 19.0 & 238.2 & 12.3 \\
\hline Cheese & 5.3 & 3.6 & 10.3 & 7.0 \\
\hline Eggs & 15.3 & 4.8 & 10.3 & 3.2 \\
\hline $\begin{array}{l}\text { Fish and } \\
\text { Seafood }\end{array}$ & 20.9 & 5.2 & 21.0 & 6.0 \\
\hline Animal fats & 17.4 & 0.3 & 6.3 & 0.1 \\
\hline Offals & 4.3 & 2.0 & 2.6 & 1.2 \\
\hline $\begin{array}{l}\text { Mutton and } \\
\text { goat meat }\end{array}$ & 0.6 & 0.4 & 0.8 & 0.8 \\
\hline Other meat & 9.8 & 3.3 & 5.2 & 1.8 \\
\hline \multicolumn{5}{|c|}{ Vegetable products } \\
\hline Stimulants & 7.8 & 1. & 8.5 & 1.7 \\
\hline Cereals & 89.6 & 20.7 & 108.6 & 27.2 \\
\hline Rice & 1.2 & 0.3 & 6.1 & 1.2 \\
\hline Fruits & 61.2 & 0.8 & 125.2 & 1.5 \\
\hline Pulses & 3.7 & 2.3 & 2.9 & 1.8 \\
\hline Starchy roots & 104.9 & 4.6 & 104.5 & 4.3 \\
\hline Vegetables & 75.5 & 2.9 & 89.4 & 3.1 \\
\hline Nuts & 0.8 & 0.2 & 2.4 & 0.4 \\
\hline $\begin{array}{l}\text { Alcoholic } \\
\text { beverages }\end{array}$ & 107.4 & 1.4 & 98.2 & 1.1 \\
\hline Oilcrops & 2.8 & 0.8 & 3.7 & 1.5 \\
\hline Spices & 0.2 & 0.1 & 1.0 & 0.3 \\
\hline $\begin{array}{l}\text { Sugar and } \\
\text { sweeteners }\end{array}$ & 49.3 & 0 & 37.5 & 0 \\
\hline Vegetable oils & 10.9 & 0 & 1.10 & 0 \\
\hline Energy use & $\begin{array}{l}\text { Energy supply } \\
\text { (units household }^{-1} \\
\text { month }^{-1} \text { ) }\end{array}$ & $\begin{array}{l}\text { Emission factor } \\
\left(\mathrm{Nr} \text { unit }^{-1}\right)\end{array}$ & $\begin{array}{l}\text { Energy supply } \\
\text { (units household }^{-1} \\
\text { month }^{-1} \text { ) }\end{array}$ & $\begin{array}{l}\text { Emission factor } \\
\left(\mathrm{Nr} \text { unit }^{-1}\right)\end{array}$ \\
\hline $\begin{array}{l}\text { Electricity } \\
(\mathrm{kwh})\end{array}$ & 156 & 0.001447 & 363 & 0.000107 \\
\hline $\begin{array}{l}\text { Natural Gas } \\
\left(\mathrm{m}^{3}\right)\end{array}$ & 35 & $0.001855^{*}$ & 98 & 0.001855 \\
\hline $\begin{array}{l}\text { Land } \\
\text { Transport }\end{array}$ & $\begin{array}{l}\text { Distance travelled } \\
\left(\mathrm{km} \mathrm{person}^{-1}\right. \\
\left.\text { week }^{-1}\right)\end{array}$ & $\begin{array}{l}\text { Emission factor } \\
\left(\mathrm{Nr} \mathbf{k m}^{-1}\right)\end{array}$ & $\begin{array}{l}\text { Distance travelled } \\
\left(\mathrm{km} \mathrm{person}^{-1}\right. \\
\left.\text { week }^{-1}\right)\end{array}$ & $\begin{array}{l}\text { Emission factor } \\
\left(\mathrm{Nr} \mathrm{km}^{-1}\right)\end{array}$ \\
\hline Private car & 108 & 0.002913 (petrol) & 164 & 0.000049 (petrol) \\
\hline
\end{tabular}




\begin{tabular}{|l|l|l|l|l|}
\hline & & 0.000309 (diesel) & & 0.000125 (diesel) \\
\hline Bus & 21 & 0.000339 & 11 & 0.000006 \\
\hline Rail & 12 & 0.000473 & 16 & 0.000005 \\
\hline Motorcycle & 1 & 0.000245 & 1 & 0.000006 \\
\hline Air transport & $\begin{array}{l}\text { Time travelling } \\
\left(\text { hours person }^{-1}\right. \\
\left.\text { year }^{-1}\right)\end{array}$ & $\begin{array}{l}\text { Emission factor } \\
\left.\mathbf{( N r ~ k m}^{-1}\right)\end{array}$ & $\begin{array}{l}\text { Time travelling } \\
\left(\text { hours person }^{-1}\right. \\
\left.\text { year }^{-1}\right)\end{array}$ & $\begin{array}{l}\text { Emission factor } \\
\left(\mathbf{N r ~ k m}^{-1}\right)\end{array}$ \\
\hline Aeroplane & 0.02 & $0.060565^{*}$ & 0.2 & 0.060565 \\
\hline
\end{tabular}

* No comparable data available for 1970 so 2007 data were used. 


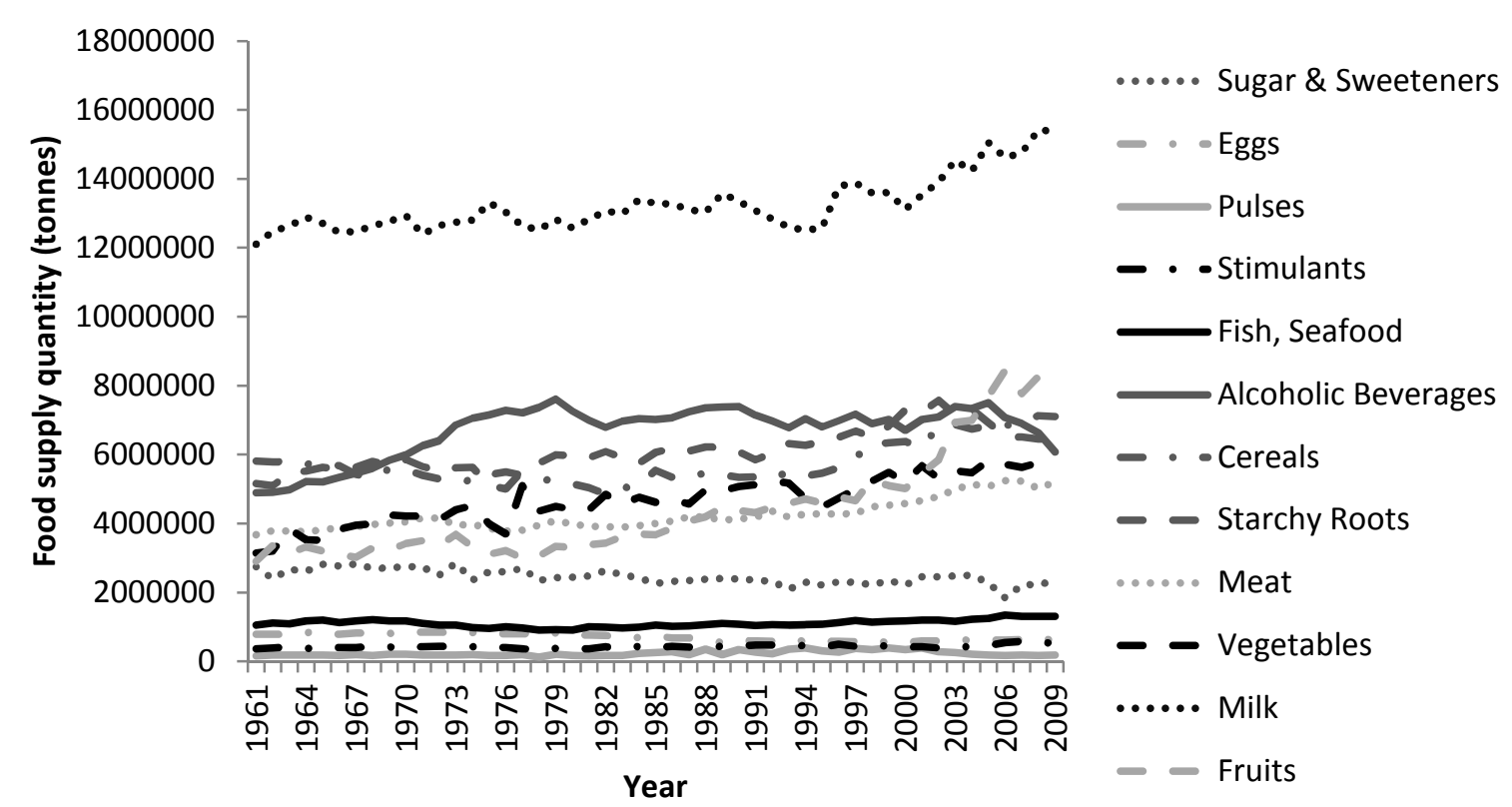

422

423

424 Figure 1. Food supply quantity (tonnes) for major food groups between 1961 and 2009 in the UK.

425 Data is taken from $\mathrm{FAO}^{8}$. 


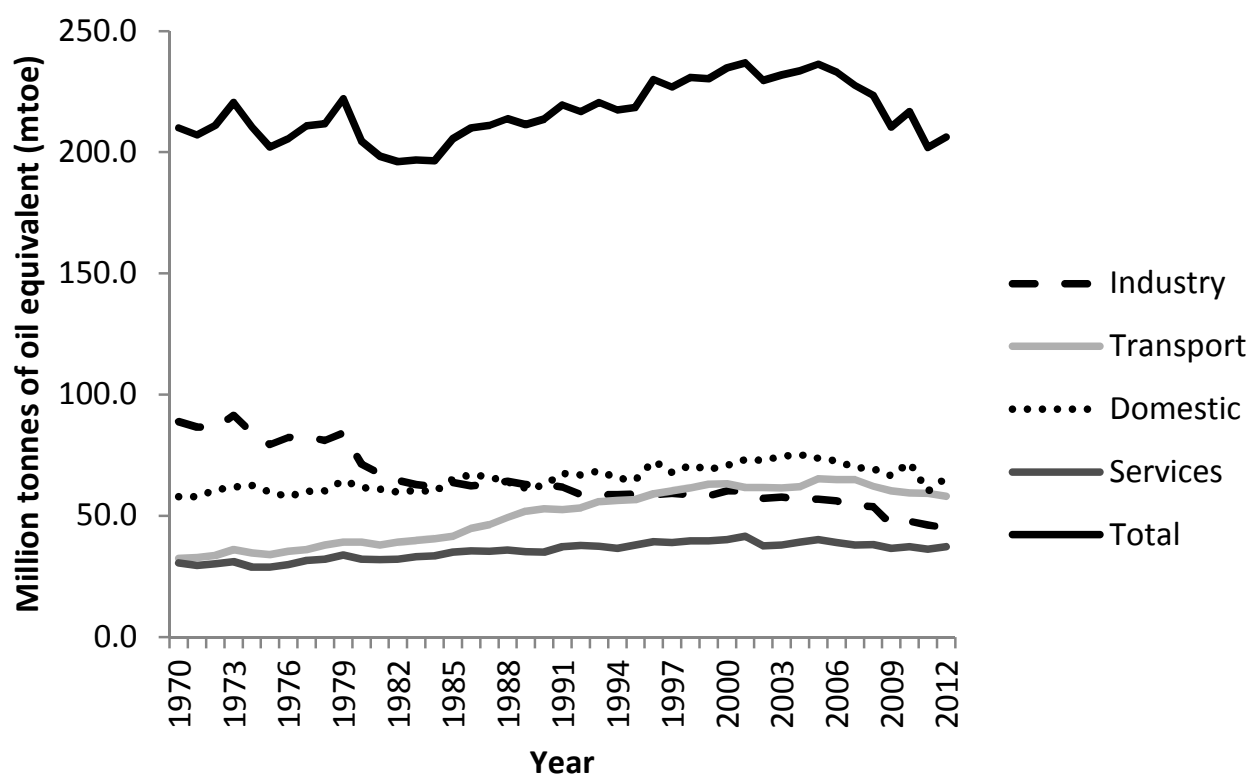

428

429 Figure 2. Energy consumption (Million tonnes of oil equivalent) between 1970 and 2012 in the UK.

430 Data is taken from the UK Department of Energy and Climate Change statistics ${ }^{43}$. 


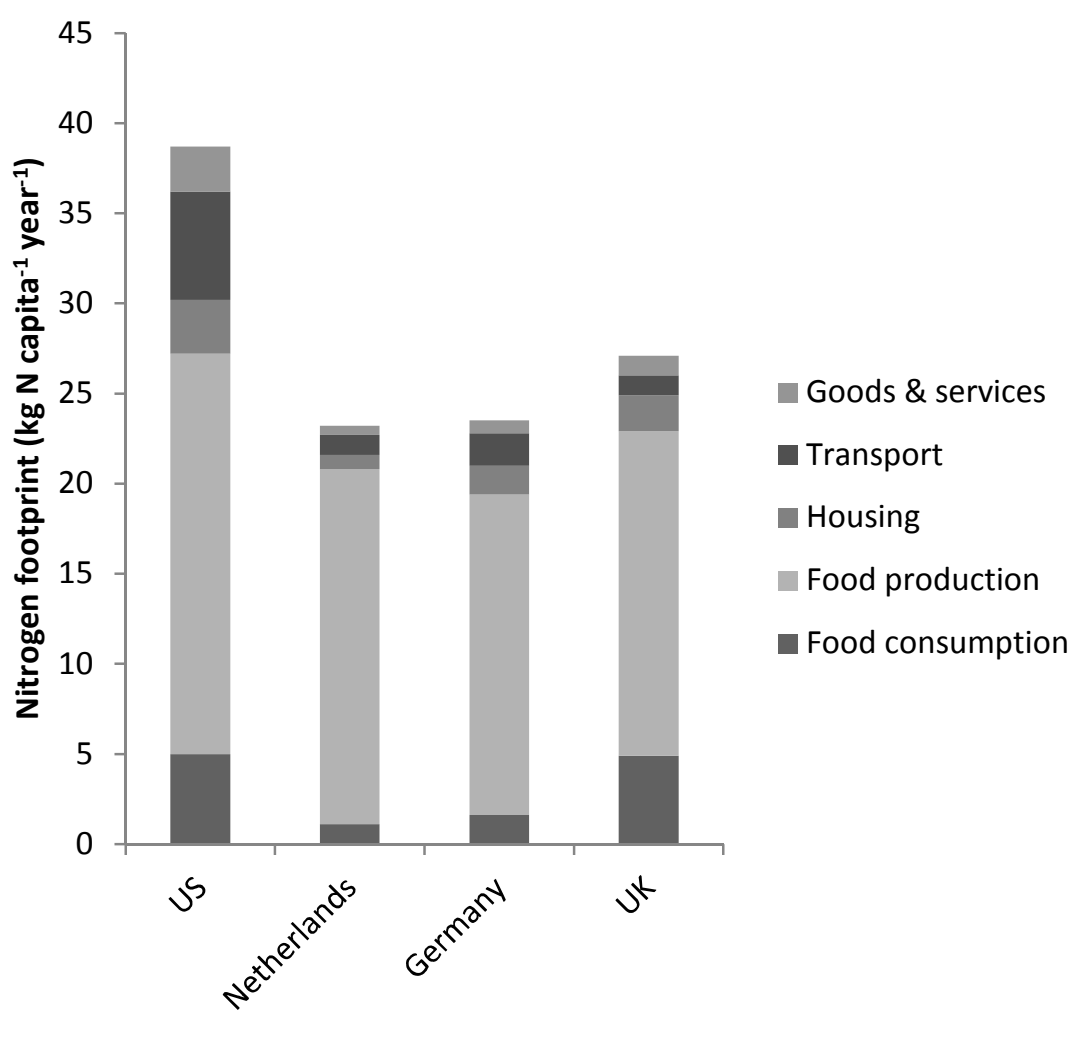

433

434 Figure 3. Nitrogen footprints (kg N/capita/yr) for the US, Netherlands, Germany and UK broken 435 down into food consumption, food production, housing, transport and goods and services. 


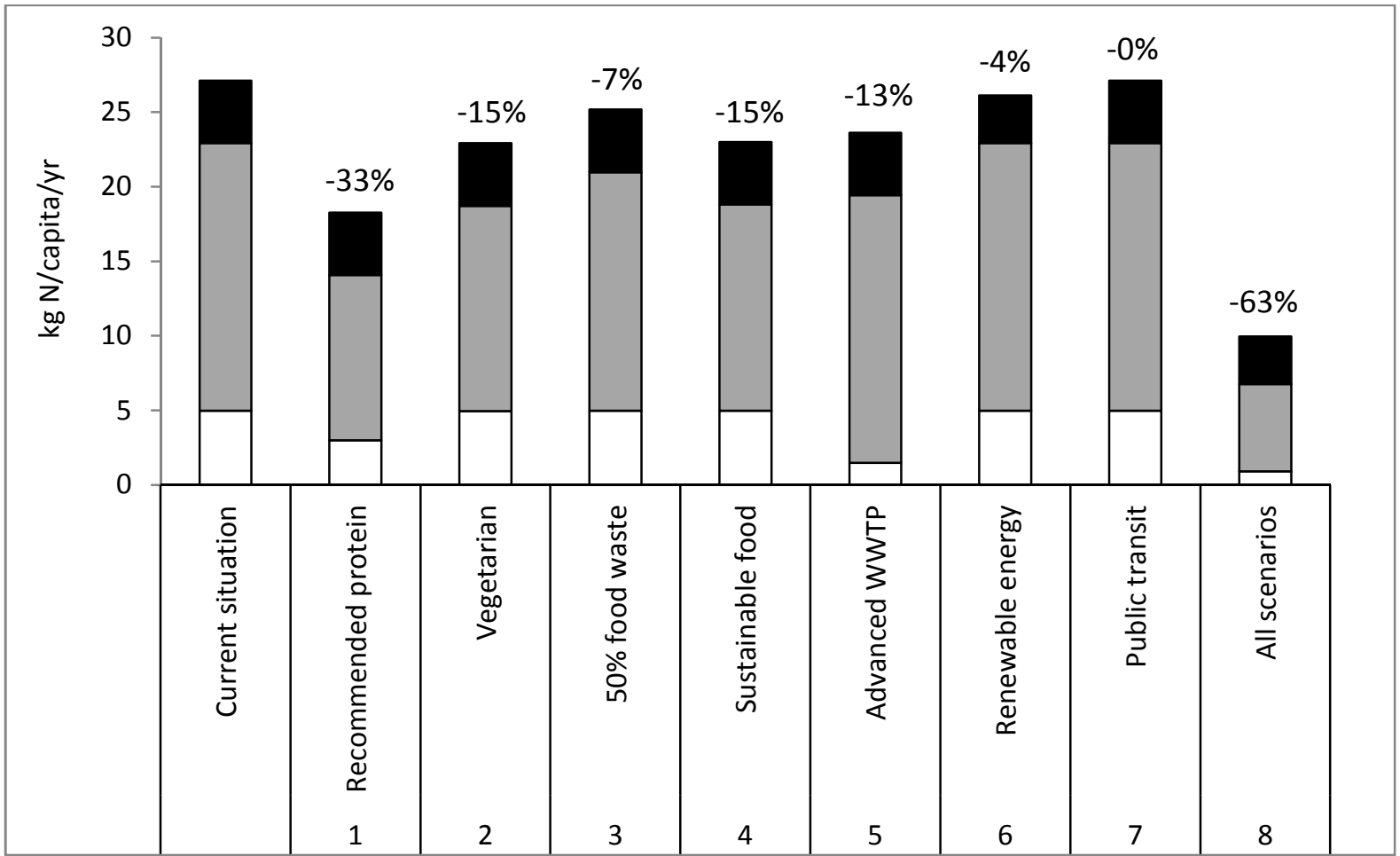

Figure 4. Impact of changes in personal consumption patterns on the $\mathrm{N}$ footprint in the United

442 Kingdom. White bars represent food N consumed, grey bars represent food virtual N, and black bars

443 represent energy $\mathrm{N}$ (i.e., from housing, transport, and goods \& services). The percentage above each

444 bar shows the percent reduction for each scenario relative to the current average UK $\mathrm{N}$ footprint. The

445 scenarios analysed are: 1) scale protein consumption down to the recommended level; 2) consume a

446 vegetarian diet; 3) reduce food waste by half; 4) consume food produced with best management

447 practices; 5) treat human waste at an advanced wastewater treatment plant (WWTP) with denitrification; 6) use only renewable energy sources for household energy; 7) use only public transit for transport; and 8) combine scenarios 1 through 7. 